\title{
The Connection Between Alzheimer's Disease and Prion Diseases: A Mini-Review
}

\author{
Hilda Martínez-Coria ${ }^{1,2}$ and Héctor E López-Valdés*1,2 \\ ${ }^{1}$ División de Investigación, Facultad de Medicina, México \\ ${ }^{2}$ Instituto Nacional de Neurología y Neurocirugía MVS, México

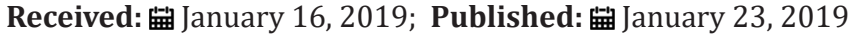 \\ *Corresponding author: Héctor E López-Valdés, División de Investigación, Facultad de Medicina, México
}

\begin{abstract}
Alzheimer's disease and prion diseases are progressive neurodegenerative disorders that have no cure. These illnesses share some similar mechanisms for misfolding, aggregation, accumulation, and dispersion of proteins; moreover, one of the receptors for amyloid beta is the normal prion protein, so several neurodegenerative diseases may share a pathological pathway.
\end{abstract}

Keywords: Alzheimer's Disease; Prion; Protein Misfolding

\section{Introduction}

Alzheimer's disease (AD) is a neurodegenerative disease with a slow progression that worsens over time [1]. AD is the main cause of dementia and this syndrome can be characterized by any reduction in cognitive capabilities that interferes with daily life [2]. There are two main forms of AD: early-onset $\mathrm{AD}$, which is rare $(\leq 1 \%)$, occurs in individuals under 65 years of age, and is caused by genetic mutations. The other form is late-onset $\mathrm{AD}$ and this is the most common form. Late-onset $\mathrm{AD}$ occurs in individuals 65 years of age and older and it is multifactorial [1]. Prion diseases, also known as transmissible spongiform encephalopathies, are a group of rare infectious neurodegenerative and fatal illnesses that includes Creutzfeldt-Jakob disease, variant Creutzfeldt-Jakob disease, Gerstmann-Straussler-Scheinker disease, fatal familial insomnia, and kuru [3]. In addition to the loss of synapses and neurons in specific brain areas, prion diseases, AD, and other neurodegenerative diseases such as Parkinson's and Huntington's disease have several other common features such as the progressive accumulation of misfolded proteins that form amyloid [4].

The main proteins involved in the accumulation of misfolded aggregates in $\mathrm{AD}$ are extracellular amyloid beta 42 (A 342 ), which forms amyloid plaques, and hyperphosphorylated tau (hp-tau), which forms intracellular neurofibrillary tangles [5]. In contrast, in prion diseases, the aggregates are formed by extracellular abnormal prion protein (PrPSc) [3]. These proteins, in their native form, undergo a misfolding process that produces a structure with $\beta$-sheet-rich structures [4]. Several studies support the hypothesis that misfolding, oligomerization, and accumulation of these proteins are the main events that trigger the pathological events in neurons in both $\mathrm{AD}$ and prion diseases [6]. A 342 , hp-tau, and PrPSc aggregation seems to adjust better to the seeding-nucleation model first proposed by Jarret and Lansbury [7].

In their current form, this model can be summarized as follows: the first event is the formation of a nucleus or seed from the misfolded monomeric protein; then, this structure evolves to oligomers, protofibrils, and mature fibrils, which eventually suffer fragmentation and the fragments produced can migrate and function as a new seed which can recruit soluble normal protein and the cycle repeats $[4,8]$. Of all the structural conformations previously mentioned, the oligomers are the more toxic form $[6,9,10]$. Experimental evidence shows that normal prion protein (PrPC) can function as an $\mathrm{A} \beta 42$ receptor and this interaction produces a decrease in long term potentiation in neurons of the hippocampus $[11,12]$. Other studies have shown that activation of PrPC stimulates hp-tau $[13,14]$, which suggests that PrPC is an intermediary between $\mathrm{A} \beta 42$ and the hyperphosphorylation of tau.

\section{Conclusion}

Strong evidence supports the hypothesis that $\mathrm{AD}$ and prion diseases have some similar mechanisms for misfolding, aggregation, and propagation, and also that PrPC can function as an $\mathrm{A} \beta 42$ receptor which is an intermediary for the hyperphosphorylation of tau. This evidence may suggest a new method for finding new therapeutic agents. 


\section{References}

1. (2018) Alzheimer's disease facts and figures. Alzheimer's Dement 14(3): 367-429.

2. Gale SA, Acar D, Daffner KR (2018) Dementia Am J Med 131(10): 11611169.

3. Colby DW, Prusiner SB (2011) Cold Spring Harbor perspectives in Biology. Prions 3(1): a006833.

4. Soto C, Pritzkow S (2018) Protein misfolding, aggregation, and conformational strains in neurodegenerative diseases. Nature Neuroscience 21(10): 1332-1340.

5. Selkoe DJ, Hardy J (2016) The amyloid hypothesis of Alzheimer's disease at 25 years. EMBO Mol Med 8(6): 595-608.

6. Ambadi Thody S, Mathew MK, Udgaonkar JB (2018) Mechanism of aggregation and membrane interactions of mammalian prion protein. Biochim Biophys Acta Biomembr 1860(9): 1927-1935.

7. Jarrett JT, Lansbury PT (1993) Seeding one-dimensional crystallization of amyloid: a pathogenic mechanism in Alzheimer's disease and scrapie? Cell 73(6): 1055-1058

8. Walker LC, Schelle J, Jucker M (2016) The Prion-Like Properties of Amyloid- $\beta$ Assemblies: Implications for Alzheimer's Disease. Cold Spring Harb Perspect Med 6(7): a024398.

\section{ISSN: 2574-1241}

DOI: $10.26717 / B J S T R .2019 .13 .002410$

Héctor E López-Valdés. Biomed J Sci \& Tech Res

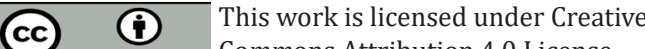

Submission Link: https://biomedres.us/submit-manuscript.php
9. Morris M, Maeda S, Vossel K, Mucke, L (2011) The many faces of tau. Neuron 70(3): 410-426

10. Miller J, Arrasate M, Brooks E, Libeu CP, Legleiter JD, et al. (2011) Identifying polyglutamine protein species in situ that best predict neurodegeneration. Nat Chem Biol 7(12): 925-934.

11. Laurén J, Gimbel DA, Nygaard HB, Gilbert JW, Strittmatter SM (2009) Cellular prion protein mediates impairment of synaptic plasticity by amyloid-beta oligomers. Nature 457(7233): 1128-1132.

12. Barry AE, Klyubin I, Mc Donald JM, Mably AJ, Farrell MA, et al. (2011) Alzheimer's disease brain-derived amyloid- $\beta$-mediated inhibition of LTP in vivo is prevented by immunotargeting cellular prion protein. J Neurosci 31(20): 7259-7263.

13. Roberson ED, Halabisky B, Yoo JW, Yao J, Chin JF, et al. (2011) Amyloid- $\beta$ / Fyn-induced synaptic, network, and cognitive impairments depend on tau levels in multiple mouse models of Alzheimer's disease. J Neurosci 31(2): 700-711.

14. Um JW, Strittmatter SM (2013) Amyloid- $\beta$ induced signaling by cellular prion protein and Fyn kinase in Alzheimer disease. Prion 7(1): 37-41.

$\begin{array}{ll}\text { BIOMEDICAL } & \text { Assets of Publishing with us } \\ \text { RESEARCHES } & \text { - Global archiving of articles } \\ & \text { - Immediate, unrestricted online access } \\ & \text { - Rigorous Peer Review Process } \\ \end{array}$

